\title{
Innovative Training in Digital Transformation
}

\author{
Mikhail Morozov ${ }^{1,2, *}$ Natalia Morozova ${ }^{2}$ Marat Moldazhanov $^{3}$
}

\author{
${ }^{1}$ Plekhanov Russian University of Economics, Moscow 117997, Russian Federation \\ ${ }^{2}$ Russian New University, Moscow 105005, Russian Federation \\ ${ }^{3}$ Kazakh Humanitarian Juridical Innovative University, Semey, Kazakhstan \\ *Corresponding author. Email: mmorozov@bk.ru
}

\begin{abstract}
Global digitalization affects all areas of socio-economic activity. It radically changes many business processes, which in turn affects the professional requirements for staff. The role and importance of digital competencies, which an employee of an enterprise should possess, is growing. The article analyzes the changes in the labor market that are caused by the influence of digitalization. It is shown that the need for innovative personnel who own modern information and communication technologies is growing. The dynamics of training innovative personnel in Russia is considered. The relationship between professional standards and educational programs has been studied.
\end{abstract}

Keywords: digitalization, digital competencies, information and communication technologies, professional

standards, educational programs

\section{INTRODUCTION}

A characteristic feature of the fourth industrial revolution is global digitalization, which penetrates into all spheres of human activity and gives rise to fundamentally new trends in the development of society. In 2019, the share of the digital economy in global GDP reached $15 \%$, in the information and communications technology sector $40 \%$ of the value added falls on the USA and China [1].

All countries and industries experience the enormous impact of digitalization based on innovative Big Data technologies, blockchain, artificial intelligence, etc. One of the indicators of the digitalization level is the availability of cellular communications and the Internet. According to the ITU (International Telecommunication Union), $90 \%$ of the world's population have access to the Internet, more than $50 \%$ constantly use the Internet [2]. According to the monitoring of the development of the information society in $2018,69 \%$ of Russian households had the opportunity to use the Internet [3].

The most important production factor in the digital economy is large amounts of data in digital form, the processing and use of which ensures the growth of production efficiency and technology.

Table 1 The proportion of the population employed in the field of information and communication technologies
Digitalization generates a fundamental restructuring of business processes; the essential content of many types of professional activity is changing. Information is becoming a key asset of enterprises and an integral part of infrastructure support for all economic entities. This leads to a change in the structure of personnel and the high demand of specialists in information and communication technologies (ICT) [4].

The aim of the work is to study the impact of digitalization on changing the labor market, the need for innovative personnel with digital competencies, the relationship of educational programs and professional standards.

\section{BACKGROUND}

Around the world, there is already a shortage of specialists in the field of information and communication technologies, which will increase over time. In the world, approximately $2 \%$ of the employed population works in the field of information and communication technologies [5]. Table 1 shows the proportion of countries with the highest ICT employment.

\begin{tabular}{|c|c|}
\hline The country & ICT Employment \\
\hline Finland & $6,8 \%$ \\
\hline Sweden & $6,6 \%$ \\
\hline Great Britain & $5,1 \%$ \\
\hline USA & $4,1 \%$ \\
\hline Germany & $3,8 \%$ \\
\hline Russian Federation & $2,2 \%$ \\
\hline
\end{tabular}


services and divisions in the field of ICT make up $4.1 \%$ [5]. Figure 1 shows the qualifications structure of ICT specialists. Figure 2 shows the distribution of information and communication technology specialists by type of economic activity in the Russian Federation [5].
In 2018 , there were 1.6 million specialists in the field of information and communication technologies in Russia, which is $2.2 \%$ of the total number of employees. Of these, more than $71.1 \%$ are specialists with the highest level of qualification, about $15.6 \%$ have an average level of qualification, skilled workers - more than $9.2 \%$, heads of

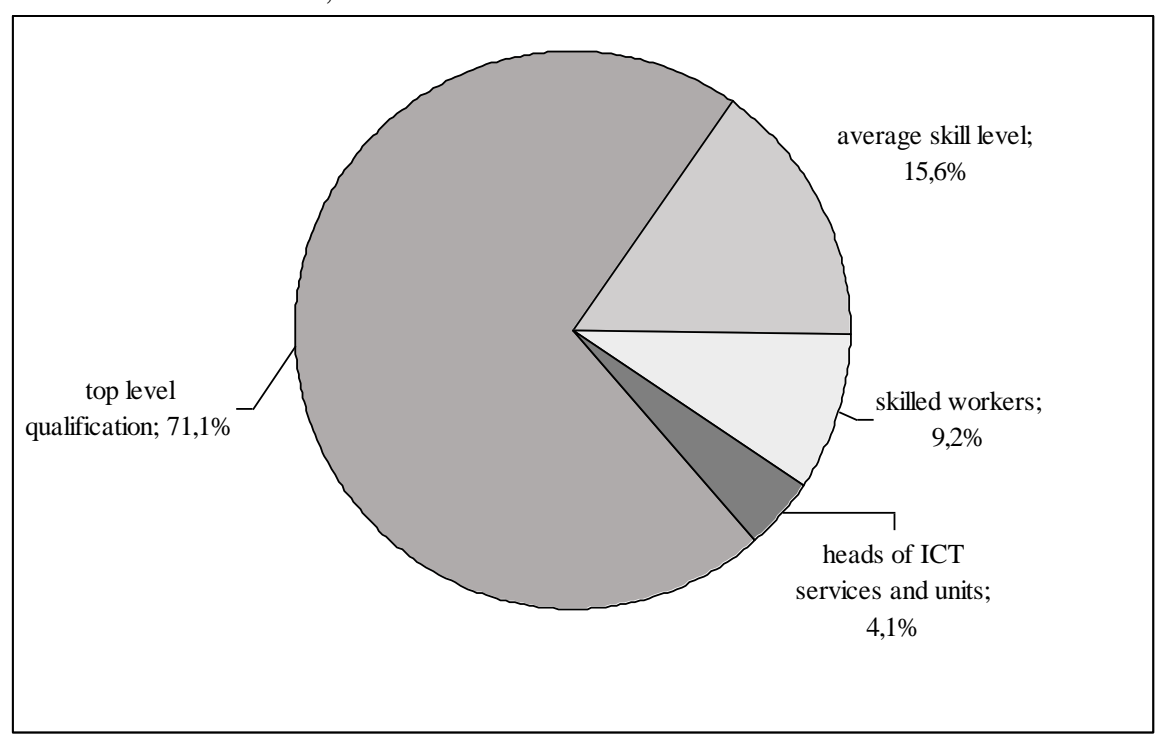

Figure 1 The qualification structure of ICT specialists in the Russian Federation

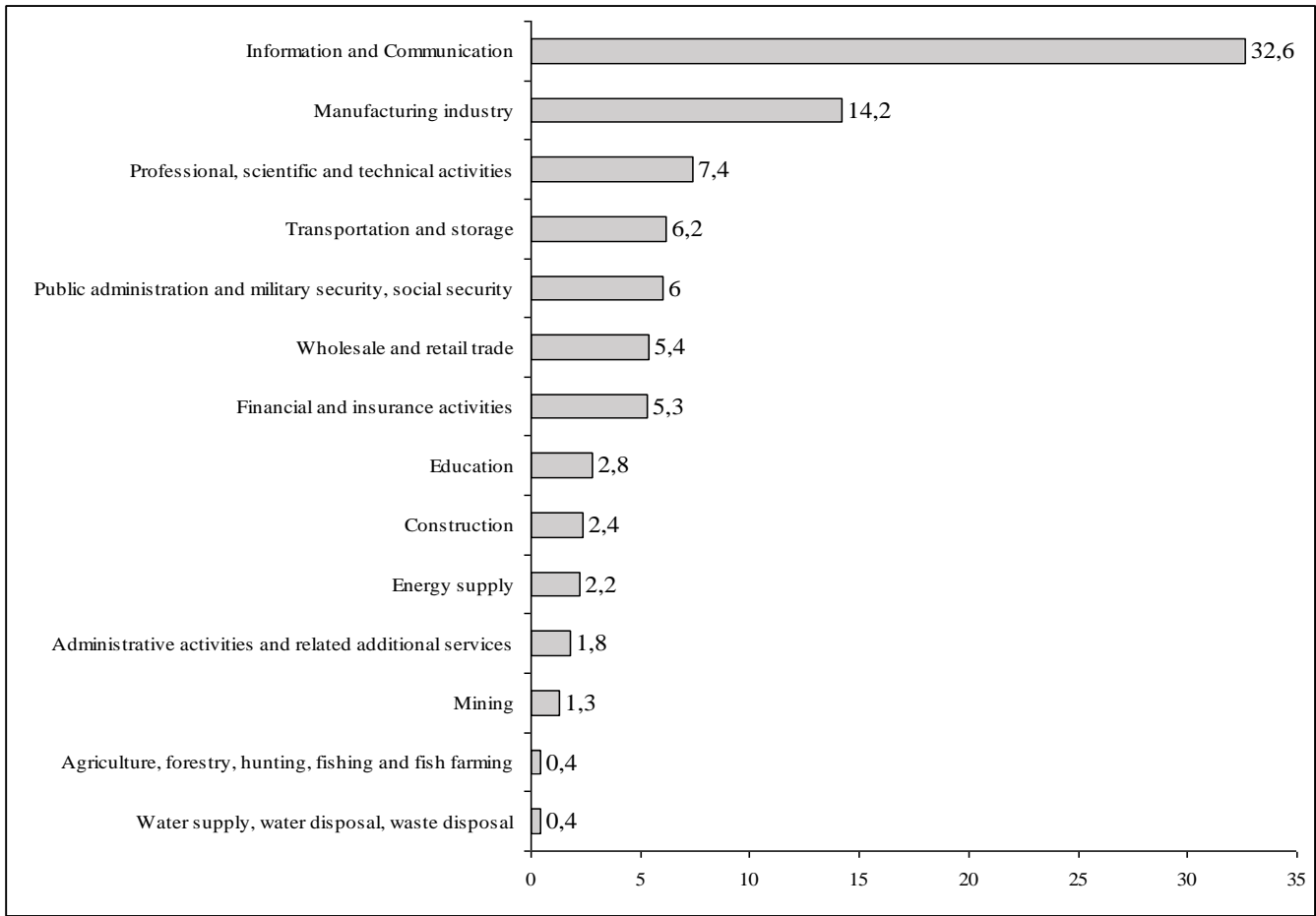

Figure 2 The share of ICT specialists employed in various types of economic activity (\%) 
Most specialists in information and communication technologies are employed in the manufacturing industry $(14.2 \%)$, construction $(2.4 \%)$, energy supply $(2.2 \%)$, and mining $(1.3 \%)$.

The shortage of specialists in the field of ICT is compounded by the fact that in the Russian Federation the total number of students enrolled in educational programs of higher education (bachelor's degree, specialty, master's program) is reduced. Figure 3 shows the dynamics of changes in the number of university students per 10,000 people in the country [6].

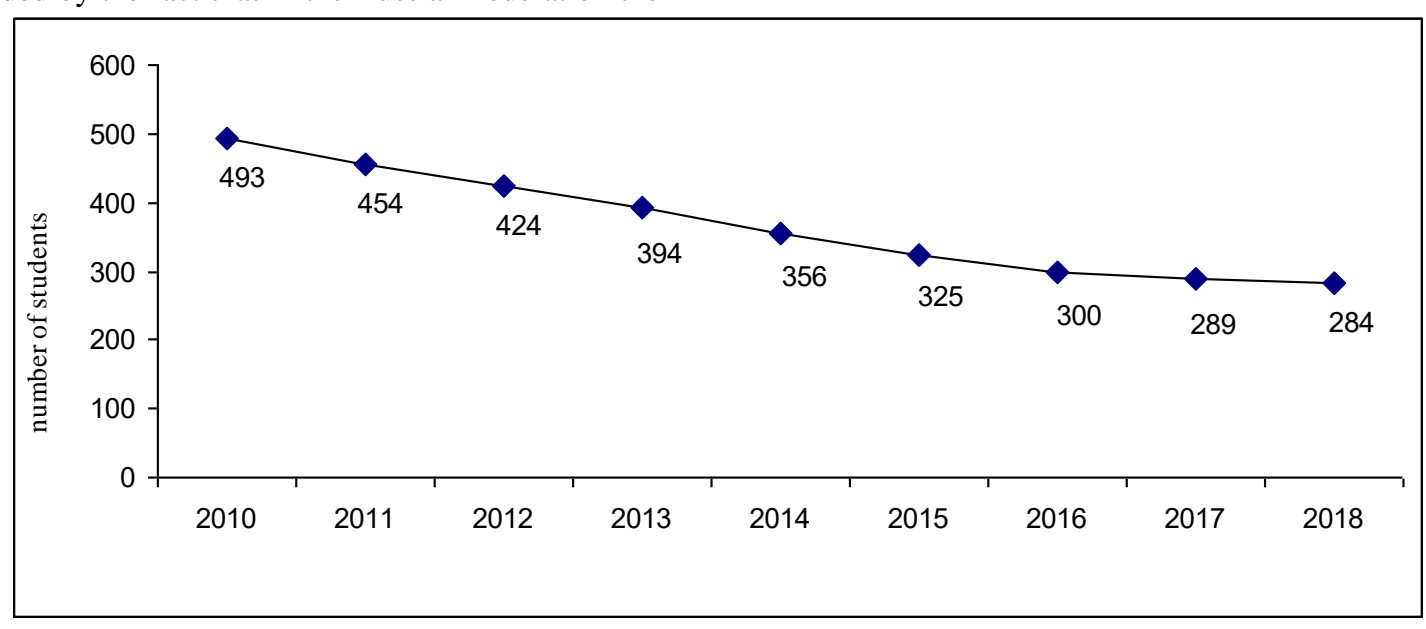

Figure 3 The number of university students per 10,000 people in the Russian Federation

From 2010 to 2018, the number of students per 10,000 people decreased from 493 to 284, i.e. 1.74 times. Only $60 \%$ of graduates get a job in their specialty. Such an unfavorable downward trend in the number of graduates with higher education will adversely affect the labor market, especially given the global digitalization. The number of students admitted to state educational institutions of higher education in the field of training "Informatics and Computing" increased per 10,000 population from 3 people in 2010 to 14 people in 2018 [6]. This is due to government policy in the distribution of the number of budget places in universities in the framework of the training areas. Significantly more budget places are allocated for training areas in the field of information and communication technologies than for other areas. The Ministry of Science and Higher Education has developed new rules for the distribution of admission control numbers in favor of regional universities, which provide training for the regions.

Global digitalization is leading to fundamental changes in the structure of the labor market. The innovative model of labor and employment "Work 4.0" provides for new types of labor activity and forms of labor. An on-demandeconomy is developing, which provides for the provision of goods and services at the moment when they are needed by the end user. Digitalization of business processes helps to increase staff mobility, expand the technology of office work, cross-border remote employment.

High technology of all business processes and their rapid changeability in the context of digitalization will require continuous training of personnel. To maintain the competitiveness of personnel, it is necessary to provide retraining and the formation of digital competencies.

In 2017, the Skolkovo Foundation assessed the degree of readiness of Russian enterprises to switch to the digital economy according to the methodology of the European Commission, which is used to assess the level of development of the digital economy [7]. The calculations took into account the use of the Internet, the integration of digital technologies, ensuring information security, the degree of staff readiness, and others. The respondents were 600 companies, 120 of which were participants in the Skolkovo project. The highest rates among enterprises in traditional industries were found in terms of Internet use $(55 \%)$ and digital integration $(40 \%)$, and the lowest in terms of readiness for human capital $(7 \%)$. At the hightech companies of Skolkovo participants, the level of development of human capital was significantly higher $20 \%$. These results indicate that Russian enterprises pay insufficient attention to training and retraining of personnel in connection with the need to switch to digital technologies. Only $8 \%$ of the enterprises in traditional industries participating in the survey dealt with the formation of digital competencies among their employees. However, $33 \%$ of high-tech companies either create their own digital technology training programs or take on the financing of staff development in other organizations.

Any technologies change much faster than people adapt to them [8]. Given the speed of digital innovation, lifelong learning will be required.

Global digitalization has contributed to the emergence of an innovative type of knowledge jobs. These jobs involve 
solving complex problems that require a creative approach and innovative solutions. In developed countries, more than $25 \%$ of such jobs, in Russia - about $17 \%$. One of the important criteria for evaluating personnel is talent [9].

The transition of enterprises to digital rails requires employees to have digital competencies, focus on selfdevelopment, quick adaptation to innovations, critical thinking, the ability to solve non-standard tasks, and communication and teamwork skills. Digital technology is growing rapidly. The main problem of digitalization will be the lack of qualified personnel capable of correctly using these technologies.

Digitalization will change approaches to assessing the competitiveness of enterprises, the most significant factors of competitiveness will be information support, computer security, digital competencies of personnel.

The dramatically increasing role of staff in the digital economy has required a revision of the existing concept of education. In the scientific works of foreign authors, studies were conducted on the impact of global digitalization on education and the need for the formation of digital competencies was substantiated $[10,11,12]$. Also studied the relationship between the concepts of digital literacy and digital competencies $[13,14,15]$

Many countries have long embarked on this task. They began implementing a digital savings strategy and restructuring the training system. Programs related to the digitalization of the economy have been developed by different countries since 2005. In Sweden, digital competencies are taken as the basis for the concept of a national strategy for digitalization of education [16]. Singapore adopted the digitalization program in 2005, Australia - 2006, Great Britain - 2008, Norway - 2009, Canada - 2010, India and New Zealand - in 2015. So far, the best digitalization results have been achieved in Singapore, Finland, Sweden, Norway, United States, Netherlands and other countries. It was in these countries that, along with the digitalization processes, they began to restructure their educational systems, take into account the needs of the digital economy and the formation of digital competencies among workers, and retrain national labor resources taking into account digitalization.

In Russia, the digitalization program Digital Economy of the Russian Federation was adopted only in 2017. It focuses on training for the digital economy. It is necessary to take into account the impact of digitalization on the needs of the labor market and develop personnel motivation systems for obtaining digital knowledge.

As part of the WorldSkills movement, specific skills that will be required in a global digital environment have been identified and formulated. They are presented in table 2 [17].

Table 2 21st Century Digital Competencies

\begin{tabular}{|c|c|}
\hline Competence & Scope of application \\
\hline $\begin{array}{l}\text { Concentration and attention } \\
\text { management }\end{array}$ & $\begin{array}{l}\text { It will form work skills in the conditions of information overload and } \\
\qquad \text { control of complex equipment }\end{array}$ \\
\hline Digital literacy & $\begin{array}{l}\text { Provides knowledge of information and communication technologies, } \\
\text { skills in the digital environment }\end{array}$ \\
\hline Creativity, creativity & Will form skills to think outside the box and create new \\
\hline Self-learning ability & $\begin{array}{l}\text { Forms the need for lifelong learning, independence in the } \\
\qquad \text { development of new skills }\end{array}$ \\
\hline Environmental thinking & $\begin{array}{l}\text { Builds an understanding of its activities in the context of the entire } \\
\qquad \text { ecosystem }\end{array}$ \\
\hline Emotional literacy & $\begin{array}{l}\text { It will form the ability to understand your emotions, provide self- } \\
\text { preservation and communication with other people }\end{array}$ \\
\hline Cross-cultural & The ability to interact with different subcultures \\
\hline
\end{tabular}

Digital competencies will become the most important and determining requirements for specialists in the context of digitalization $[18,19]$. In training programs, it is necessary to provide for the formation of specialized digital skills related to solving complex professional problems in the digital environment, the skills of high-tech professions (programmers, web designers, big data analysts, etc.). 
Digitalization of production requires the specialist to have professional competencies in the field of management and quality control. Also, supraprofessional competencies include systems engineering thinking, project management, lean manufacturing, programming, intersectoral communication, creative skills, and environmental thinking. To work in a digital economy, new digital skills will be required that must be addressed in educational and professional standards. These standards should be updated periodically with the development of new digital technologies.

The qualifications and professionalism of employees must be maintained at a high level throughout their work. This is done through the development of various educational retraining programs, as well as through the acquisition of practical work experience. Educational programs for training and retraining of personnel should take into account the requirements of professional standards, as well as relevant competencies and modern needs of the labor market.

Professional standards define the qualifications of workers for the performance of labor functions. An independent qualification assessment is carried out to determine whether an employee's qualifications meet the requirements of a professional standard. The development of professional standards in the Russian Federation began in 2013. At the beginning of 2020, in the register of professional standards, there were more than 1300 professional standards in all areas of activity.

Professional standards systematize qualification requirements, streamline the labor market, and ensure the interconnection of education and the labor market. Professional standards reflect current requirements, which are dictated by the achieved level of development of engineering and technology in the relevant industries. In other words, professional standards reflect the state of the economy and technologies that exist in a certain time interval. However, they do not reflect future changes in the labor market and do not present advanced requirements for the qualifications of personnel.

The development of professional standards was also focused on combining the educational community and business in terms of the demand for graduates of educational institutions. The professional business community, when developing its professional standards, must precisely define and formulate the requirements for knowledge and skills that an employee of the enterprise should possess. Based on this, educational programs should be created for the training of personnel in demand on the labor market. The National Qualifications Framework (NQF), which provides a generalized description of qualification levels and the main ways to achieve them, acts as a mechanism for reconciling the needs of the labor market and the possibilities of the educational system. In educational programs, the relationship with professional standards must be traced. An analysis of the relationship of professional standards and educational programs was carried out by us in article [20]. Depending on the level of education, this relationship can be implemented to varying degrees. For example, undergraduate degree programs should be as professional as possible, as they are focused on meeting the current needs of the labor market. In the educational programs of graduate and postgraduate programs, professional standards can no longer be considered as a benchmark, it should be considered as a minimum basic component. Professional standards reflect the achieved level of scientific and technological progress in the relevant industry, and the training of highly qualified personnel involves the development of competencies associated with the acquisition of new knowledge. Thus, in educational programs, innovative technologies of the digital economy should be taken into account.

\section{CONCLUSION}

Training innovative personnel for the digital economy is one of the most important tasks, as digital human resources determines the success of the development of the national economy. It is necessary to carry out work in the following main areas:

- improve the education system in order to provide the digital economy with competent personnel,

- monitor the labor market taking into account the requirements of the digital economy,

- update professional standards and educational programs in accordance with changes in the labor market.

\section{REFERENCES}

[1] Digital Economy Report 2019. UN. Geneva. URL: https://unctad.org/en/PublicationsLibrary/der2019_over view_ru.pdf.

[2] ITU releases 2018 global and regional ICT estimates. - URL:

https://www.itu.int/en/mediacentre/Pages/2018PR40.aspx/ 33

[3] Monitoring the development of the information society in the Russian Federation - URL: https://www.gks.ru/free_doc/new_site/figure/anketa14.html

[4] Morozov MA, Morozova NS The development of the digital service economy and its impact on the labor market // Service plus, 2018, T.12. No. 1, S. 94-101.

[5] Indicators of the digital economy: 2019: statistical compilation / G.I. Abdrakhmanova, K.O. Vishnevsky, L.M. Gokhberg and others; Nat researched University "Higher School of Economics",M.: HSE, 2019, 248 p.

[6] Monitoring the development of the information society in the Russian Federation - URL: 
[14] Measuring the Information Society Reports. (2018). Geneva Switzerland: International Telecommunication Union.

[15] Moncada Linares, S., \& Díaz Romero, C. (2016). Interdisciplinary Journal of e-skills and Life Long Learning, 12, 57-93.

[16] Swedish Ministry of Education. (2017). Nationell digitaliseringsstrategi för skolväsendet U2017 / 04119 / S. Retrieved December 7, 2017 from: http: //www.reger ingen.se/4a9d9a/contentassets/ 00b3d9118b0144f6bb95302f3e08d11c / nationell-digi taliseringsstrategi-for-skolvasendet.pdf

[17] Skills of the future. What you need to know and be able to in a new complex world, WorldSkills Russia, Global Education Future - 2018 - URL: https://worldskills.ru/assets/docs/media/WSdoklad_12_ okt_rus.pdf

[10] L. Ilomäki, S. Paavola, M Lakkala \& A. Kantosalo,. Digital competence - An emergent boundary concept for policy and educational research. Education and Information Technologies, 21 (3), (2016) 655-679. DOI: 10.1007 / s10639-014-9346-4

[11] Morellato, M. (2014). Digital competence in tourism education: cooperative-experiential learning. Journal of Teaching in Travel \& Tourism, 14 (2), 184209. doi: $10.1080 / 15313220.2014 .907959$.

[12] Spante1, M., Sofkova, S., Lundin, M., Algers A. (2018). Digital competence and digital literacy in higher education research: Systematic review of concept use. Cogent Education. https://doi.org/10.1080/2331186X.2018.1519143

[13] Iordache, C., Mariën, I., \& Baelden, D. (2017). Developing digital skills and competences: A quickscan analysis of 13 digital literacy models. Italian Journal of Sociology of Education, 9 (1), 6-30.
[18] M.A. Morozov. Personnel management at the enterprises of the tourist industry, Standards and quality. 2 (2006), pp. 54-58.

[19] B. Van Ark. The Productivity Paradox of the New Digital Economy. International Productivity Monitor 31: (2016), pp. 3-18.

[20] M.A.Morozov, N.S. Morozova Approaches to assessing the compliance of educational programs with professional standards, Higher Education Today. 10 (2017). pp.13-17 